\title{
LONG-TERM CHANGES OF COPEPODA (CRUSTACEA) ABUNDANCE AND BIOMASS IN THE DANUBE AND ODESA REGIONS OF THE BLACK SEA AS INDICATOR OF WATER QUALITY
}

\section{Yuliia Kharytonova ${ }^{1}$ Vasil Dyadichko ${ }^{2}$}

DOI: https://doi.org/10.30525/978-9934-26-077-3-21

Abstract. Copepoda are the most important zooplanktonic group constituting the primary food for fish larvae and some fishes. Copepoda have the longest life cycles among the Black Sea mesozooplankton, so their biomass and percentage of total zooplankton biomass is greatly reduced by eutrophication. The percentage of Copepoda from the total biomass of zooplankton is a reliable indicator of the ecological status of the water bodies. For the Black Sea marine waters the indicator of "good" ecological status (GES) is the average annual biomass of Copepoda, which exceeds $45 \%$ of the total biomass of zooplankton. Changes of total biomass of zooplankton, biomass of Copepoda, the abundance and biomass of dominant species - Oithona davisae Ferrari F. D. \& Orsi, 1984, Acartia (Acartiura) clausi Giesbrecht, 1889 and A. (Acanthacartia) tonsa Dana, 1849 in the Danube and Odesa marine regions from 1970 to 2019 were analysed. Also the ecological quality class in the Nort-Western part of Black sea by Copepoda indicators from 2004 to 2017 were established according to Water Framework Directive US. The total zooplankton biomass had been decreasing in Ukrainian waters and \% of Copepoda from total zooplankton biomass was increasing. These tendencies shown a positive change in the forage base of commercial planktophagous fishes and ecological class status of the investigated aquatories. The abundance and biomass of $O$. davisae, A. clausi and $A$. tonsa were decreased from 2016 to 2019. The highest values of their metrics were in 2016 and the lowest rates observed in 2019.

\footnotetext{
${ }^{1} \mathrm{PhD}$-student, Engineer at Institute of Marine Biology of the National Academy of Sciences of Ukraine, Ukraine ${ }^{2}$ Ph.D, Senior Researcher, Institute of Marine Biology of the National Academy of Sciences of Ukraine, Ukraine
} 
$O$. davisae, A. clausi and A. tonsa were the main components of copepods number and biomass. The Acartia species formed higher part of Copepoda biomass than $O$. davisae. The ecological state was "good" (GES) only in Danube-Dnieper coastal waters and Danube delta in 2004-2017 where Copepoda formed more than $45 \%$ of total zooplankton biomass. In waters of Northwester Black Sea bays, shallow and deepwater shelfs the ecological state was "Bad" (notGES), the part of Copepoda was lower than $45 \%$.

\section{Introduction}

The Black Sea ecosystem have been in a dynamic state over the past several decades as a whole and its individual water area. For various reasons the development of some species decreases or increases, others disappear, new ones are introduced for the ecosystem $[15$, p. 80].

Zooplankton is the most important component of the food chain in seas and oceans. Copepods are the most important mesozooplanktonic group constituting the primary food supply of fish larvae and some fishes that having high economic value [1, p. 685; 4, p. 224].

From time to time Mediterranean species of copepods have been recorded in the Black Sea plankton near the Bosporus area. However, few organisms can survive in the conditions of the Black Sea to the low salinity and large variations in temperature. The ecological conditions of the Black Sea have changed substantially in the last 50 years and the introduction of new species has led to changes in the ecosystem [9, p. 28; 14, p. 120].

In particular the introduction of Mnemiopsis leidyi A. Agassiz, 1865 in the 1980s led to a decrease in zooplankton density and change copepod diversity due to the heavy predation impact of this ctenophore. Some copepods species, such as Oithona nana Giesbrecht, 1893, Paracartia latisetosa (Krichagin, 1873), and Acartia (Acartiura) margalefi Alcaraz, 1976, completely disappeared from the Black Sea ecosystem during this destructive period. After the large-scale collapse of the Black Sea ecosystem, the devastating effects of $M$. leidyi were attenuated following the introduction of Beroe ovata Bruguière, 1789, which is a voracious predator of M. leidyi. Subsequently, the species lost from the Black Sea ecosystem have been replaced by other species that share a similar ecological niche. Therefore, the absence of $O$. nana together with the decrease of M. leidyi provided the opportunity for Oithona davisae Ferrari F. D. \& Orsi, 1984 
to successfully invade the Black Sea. Individuals of this species not only could survive in Black Sea conditions, but also had established populations [2, p. 1008].

Some specimens of a cyclopoid copepod new to the Black Sea were found in Sevastopol Bay in December 2001. The zooplankton species $O$. davisae is indigenous to coastal areas of Japan and the China Seas. However it had successfully invaded in many other coastal marine regions such as San Francisco Bay, the Mediterranean Sea, the North Sea and the Black Sea. It had transported in ballast water tanks. The species was identified as Oithona brevicornis Giesbrecht, 1891. Recently, the species was re-identified as $O$. davisae [3, p. 258].

O. davisae is a pelagic cyclopoid copepod. The naupliar and copepodite stages are separated into six stages each. $O$. davisae has a wider potential salinity tolerance due to the estuarine lifestyle, due to which it has a higher body density, exhibits greater motor activity and the rate of oxygen consumption, the value of which is comparable to the theoretically expected respiration rate of calanoid copepods [3, p. 259].

For the period 2005-2013 In the Odesa sea region and the Danube region, the zooplankton structure was replenished with new Black Sea alien species -O. davisae. An outbreak of development of $O$. davisae was noted in September 2012, when it completely replaced the native form of Oithona minuta T. Scott, 1894. Its population was 35459 specimens and biomass were $85.53 \mathrm{mg} / \mathrm{m}^{3}[5$, p. 61].

In the Odesa marine region in 2013 and 2014 were also identified 159 specimens of $O$. davisae (biomass $-4 \mathrm{mg} / \mathrm{m}^{3}$ ). With an increase in the abundance of the $O$. davisae was observed a further decrease in the abundance of Oithona similis (Claus C., 1866), that was not recorded in samples from 2013) [5, p. 62].

In the last ten years, the alien species of cyclops $O$. davisae has appeared in the North-Western part of the Black Sea. In the North-Western part of the Black Sea, O. davisae had been observed since 2011. Its was completely naturalized in North-Western part of the Black Sea and belongs to the dominant taxa not only among Copepoda, but also of all zooplankton. It should be noted that this omnivore species belongs to the feed for fish zooplankton, therefore, its mass development may had a positive effect on fish-planktophages [14, p. 120]. 
Three species of the genus Acartia were reported from the Black Sea: Acartia clausi Giesbrecht, 1889, Acartia latisetosa (Krichagin, 1873), Acartia italica Steuer, 1910. A. clausi small form for the Black Sea was described by Potemkina in 1940 . Nowadays it has been reported as A. margalefi. Acartia tonsa Dana, 1848 is an abundant neritic species common in coastal waters of the Western Atlantic, Indian and Pacific Oceans. The populations of $A$. tonsa can reach great. However, in both Mediterranean and the Black seas $A$. tonsa was discovered relatively recently. For the Black Sea $A$. tonsa was reported as late as in 1994. The copepod was found in plankton samples collected in September 1990 near Karadag, in the south-eastern part of Crimea. Later, relatively high abundance of $A$. tonsa was recorded in the southern part of the Black Sea and in Sevastopol Bay [6, p. 231; 12, p. 106].

A. tonsa is identified by adults. In August 2005, an outbreak of its development was observed in the Odesa Bay. The ratio of A. clausi and A. tonsa were 1: 137 [5, p. 61].

An increase in the abundance of an alients speacies and an expansion of its habitat leads to a change in the structure of native communities and the characteristics of their functioning. This is especially important due to the fact that the new invaders are a representative of mesozooplankton, which are the central component of marine ecosystems and provides a connection between primary production and consumers of the 1st and 2nd orders. Many fish depend on zooplankton as a food source at different stages of their life cycle. Moreover, if the survival of fish eggs and prelarvae mainly depends on abiotic factors and the influence of predators, then at all subsequent stages of development - on the provision of food, the main component of which is zooplankton. Therefore, quantitative and qualitative changes in zooplankton are a leading indicator of what will happen to fish stocks. Numerous studies have shown that the nauplii and copepodite stages of Oithona spp. and other small copepods are the most important food source for fish larvae and other planktivorous predators [3, p. 263].

Populations of $O$. davisae initially became established in coastal waters but later were detected in the off-shore waters of Black Sea. These findings demonstrate that the distribution of $O$. davisae, which is an epipelagic-neritic species, gradually expanded in the Black Sea year by year, as population abundance also increased. The non-indigenous species 
settling in the coastal zone have to adapt to wide variability in salinity and temperature. The majority of holoplanktonic copepods are assumed to be osmoconformer. With their experimental study, Svetlichny and Hubareva demonstrated that the salinity tolerance of $O$. davisae was between 3 and $40 \%$. [3, p. 259]. They also stated that the osmoregulatory abilities of $O$. davisae might facilitate their successful adaptation to the brackish Black Sea [3, p. 262]. O. davisae is found at temperatures between 8.9 and $28.2^{\circ} \mathrm{C}$. Its high tolerance to varying environmental conditions allows $O$. davisae to survive and reproduce in the Black Sea [9, p. 33]. The feeding strategy of $O$. davisae contributes to its widespread distribution in the ecosystem. O. davisae is microflegellat feeder [11, p. 418].

Copepoda have the longest life cycles among Black Sea zooplankton, so their biomass and percentage of total zooplankton biomass is greatly reduced by eutrophication. It is well known that in anthropogenic eutrophication of any type of aquatic ecosystems, short-cycle organisms play a leading role in the formation of zooplankton biomass. Thus, the percentage of Copepoda from the total biomass of zooplankton is a reliable indicator of the ecological status of the water area [8, p. 226].

Acording to the European Water Framework Directive(WFD; 2000/60/EC) $[10$, p. 84$]$ waters quality may be divided into two classes: "good environmental quality (GES)" and "poor environmental quality (NotGES)", which, on a five-point scale, are GES - "high and good water quality" and NotGES "medium, poor and bad water quality" respectively [1, p. 28; 8, p. 225].

For the Black Sea marine waters, the indicator of "good" ecological status (GES) is the average annual biomass of Copepoda, which exceeds $45 \%$ of the total biomass of zooplankton [8, p. 226].

The aim of the work is to reveal the long-change in the abundance and biomass of main components of Copepoda-O. davisae and A. clausi in the Danube and Odesa regions of the Black Sea and to determine the quality of these aquatorias by copepods indicators.

\section{Materials and methods}

To analysis the long-term dynamics of the abundance and biomass of main components of Copepoda - O. davisae, A. clausi and A. tonsa in the Danube and Odesa marine regions and to establish the ecological quality class in Nort-Western part of the Black sea had been analised a databases 
of the Institute of Marine Biology of the National Academy of Sciences of Ukraine and the data collected in the framework of the international project "Emblas-plus" (Improving environmental monitoring of the Black Sea selected events) during the ukrainian-georgian expeditions "National pilot monitoring studies" (NPMS) and "Joint Black Sea survey" (JBSS) during 2016, 2017 and 2019.

Maps of the stations of monitoring and collection of zooplankton samples by the Institute of Marine Biology of the National Academy of Sciences of Ukraine are presented in Figures 1 and 2.

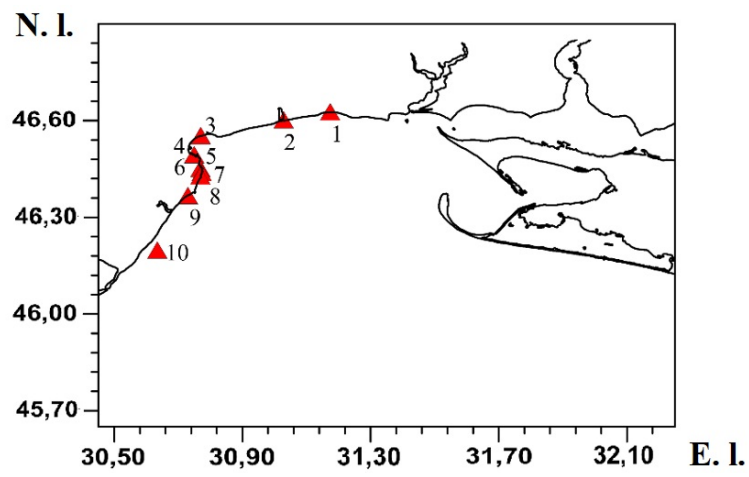

Figure 1. Map of zooplankton sampling stations during long-term monitoring of the Odesa marine region

In the period from 2016 to 2019 collected samples had contained the copepods $O$. davisae, $A$. clausi and $A$. tonsa. In 2016 O. davisae had been observed in 23 samples, in 2017 - in 22 samples, in 2018 - in 12 and in the 2019 in 17 samples of zooplankton. A. clausi and A. tonsa were found in 2016 in 25 samples, in 2017 - in 22, in 2018 - in 12, and in $2019-$ in 21 samples of zooplankton.

In all expedition zooplankton samples were taken using a standard Juday plankton net with the mouth area of $0.1 \mathrm{~m}^{2}$ and mesh size $150 \mu$. Samples were fixed with buffered formaldehyde solution (4\% final concentration). The samples were processed under binocular microscope. Abundance and biomass of Copepoda were determined according the standard methodology for studies in the Black Sea [7, p. 5]. 


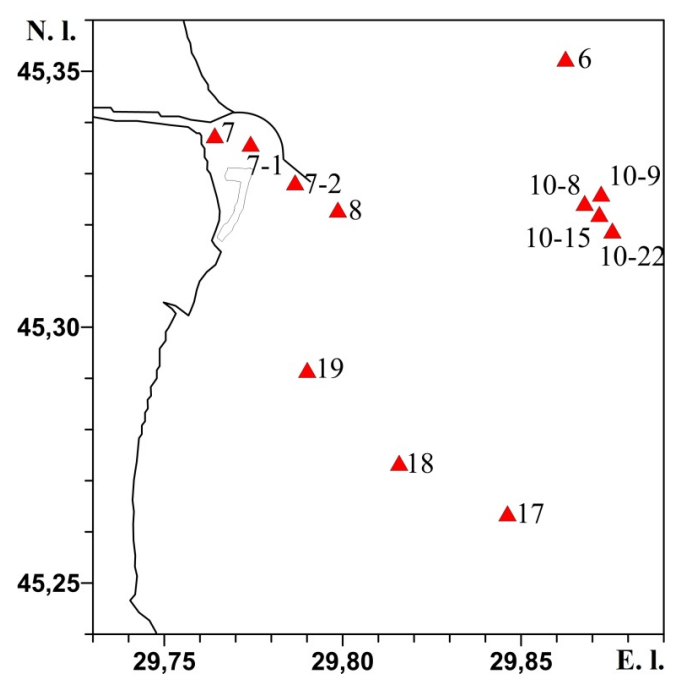

Figure 2. Map of zooplankton sampling stations during long-term monitoring of the Danube region

To determine the dynamics of Copepoda and the total biomass of zooplankton in the investigations aquatories had been analyzed the historical databases of the Institute of Marine Biology of the National Academy of Sciences of Ukraine from 1970 to 2019. Also were taken a samples of zooplankton during monitoring of state of zooplankton and its forage base in Ukrainian marine and transitional waters in framework of project "Emblas-plus" in 2016-2019.

Determination of threshold values between "good" ecological status (GES) and "poor" ecological status (NotGES) in the national waters of Ukraine was carried out in the following areas of the Black Sea: DanubeDniester region (C3), Danube avandelta (T1), Northwester Black Sea bays (C9), shallow shelf (Sh4) and deepwater shelf (Sh6) (Figure 3).

For marine waters of the Black Sea, the indicator of "good" ecological status (GES) is the average annual biomass of Copepoda, which exceeds $45 \%$ of the total biomass of zooplankton.

To determine the ecological status class of marine and coastal waters of Nort-Westetn part of the Black sea for each study area was found the 


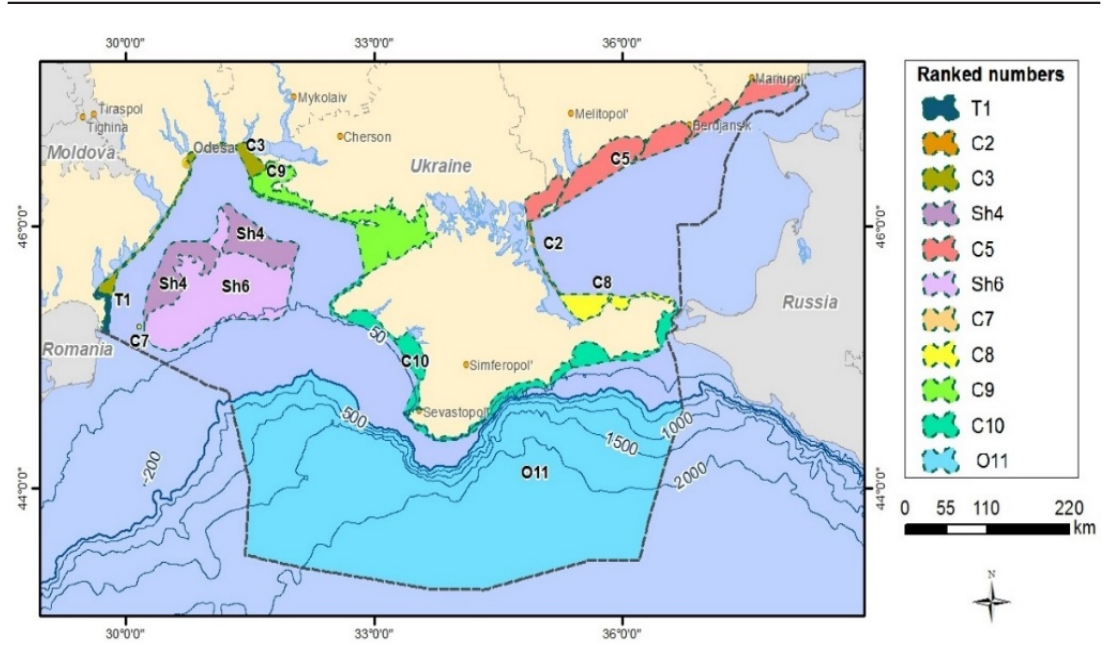

Figure 3. Black Sea monitoring subregions in 2007-2019 [8, p. 222]

maximum, minimum and average value of Copepoda biomass from the total biomass of zooplankton from 2004 to 2017.

\section{Results of investigation. Dynamics of the total biomass of zooplankton in the Odesa and Danube regions of the Black sea in 1980-2019}

$O$. davisae, A. clausi and A. tonsa are the main components of forage zooplankton. They biomass makes up a significant proportion of the total biomass of Copepoda. As a result of the analysis of average annual values can saw that the total biomass of zooplankton had decreased considerably in the last years. The largest biomass in the Odesa region was observed in the period from 1970 to 1980 (Figure 4).

Over the next decade, that metric successfully had decreased. In the 1990s, zooplankton biomass had increased, but declined in next years again. In the next decade was the same tend to decreasing. The largest biomass of zooplankton was observed in the Danube region in the $1980 \mathrm{~s}$, but significantly had decreased in the 1990s. In 2000s biomass was increased a noticeable. But in the last 10 years the situation is the same as in the Odesa region - the biomass of total zooplankton was fallen. 


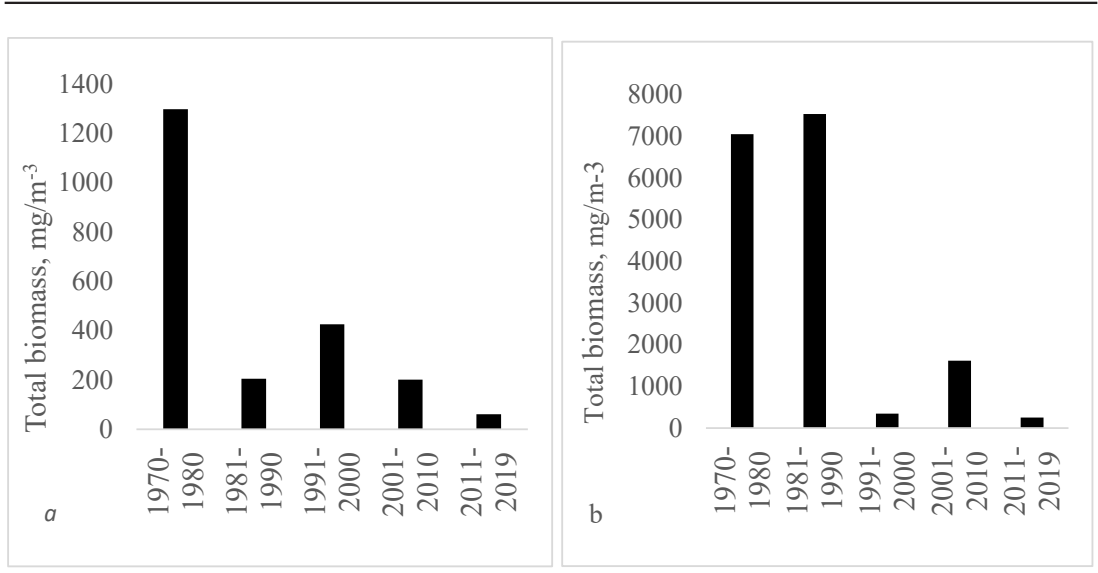

Figure 4. Long-term changes of total biomass of zooplankton: $a$ - in the Odesa region; $b$ - in the Danube region; Axis $X$ - periods, Axis $\mathrm{Y}$ - total biomass of zooplankton, $\mathrm{mg} / \mathrm{m}^{3}$

During the work were investigated the long-term changes in the biomass and abundance of total Copepoda. Were determined the average annual values from 1970 to 2019 in the Danube region and the Odesa region (Figure 5).

During the results of long-term monitoring the Copepoda biomass in the Odesa bay was at the same level and practically did not change from 1970 to 2000. But in the 2000s was a slight change to decreasing of this indicator. And from 2011 to the present the biomass of copepods significantly had increased.

In the Danube region, the dynamics of copepod biomass was different. From 1970 to 1990 , this metric was low and the same over the 20 years. But since 1991 the biomass had increased twice, then since the 2000s it had decreased again. And since from 2011 had been notice a tendency to its increasing. Biomass of Copepoda in next years was the highest among all the years of the investigation.

It is well seen that total zooplankton biomass had decreased in Ukrainian waters and \% of Copepoda from total zooplankton biomass was increasing. These tendencies shown a positive change in the forage base of commercial planktophagous fishes and ecological class status of the investigated aquatories. 


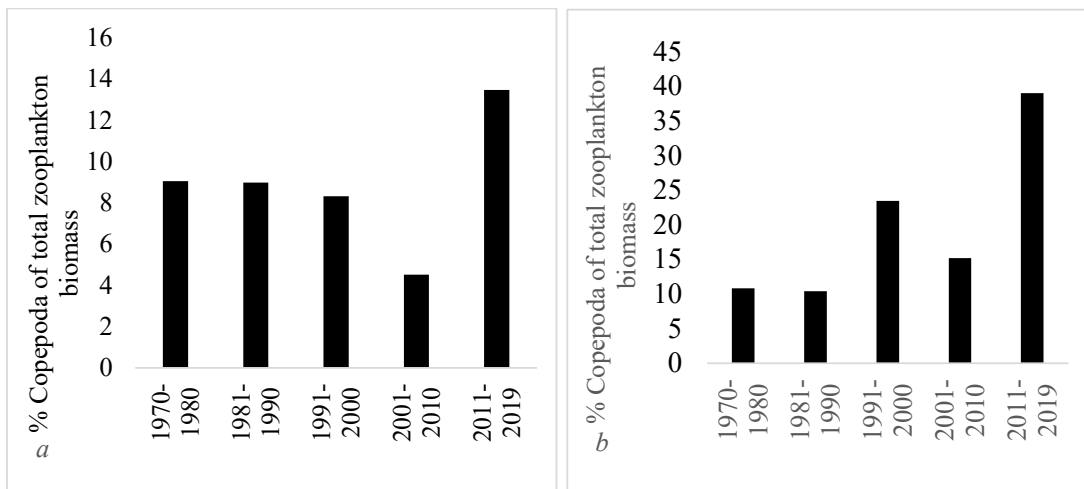

Figure 5. Long-term changes percentage of Copepoda of total zooplankton biomass: $a$ - in the Odesa region; $b$ - in the Danube region; Axis X - periods, Axis Y - Copepoda of total zooplankton biomass, \%

\section{Dynamics of the total biomass of zooplankton and Copepoda in the Danube avandelta in 2007-2017}

Also was carried out the analysis of changes in the total biomass and biomass of Copepoda in the Danube avandelta and in its coastal zone. In Danube avandelta in the period 2007-2017 were significant annual fluctuations of the abudance and biomass of zooplankton with a general tendency to decrease (Figure 6).

The figure shown that the highest indicator of total zooplankton biomass had observed in $2007\left(4921 \mathrm{mg} / \mathrm{m}^{3}\right)$. It was higher than from all next years, when its indicator did not exceed $1000 \mathrm{mg} / \mathrm{m}^{3}$. After 2007, the highest indicator of zooplankton biomass had observed in 2012-2013 and 2015, and in 2016-2019 the biomass decreased again.

It is important to note that after 2009 there was a significant restructuring of the structure of the zooplankton group, the dominant taxa had changed and was appeared the new species $O$. davisae. If in 2004-2008 the basis of zooplankton biomass was formed by the Noctiluca scintillans (Macartney) Kofoid \& Swezy, 1921, but since 2010 the leading role in the formation of biomass has shifted to copepods, primarily species of the genus Acartia and the alient $O$. davisae. 


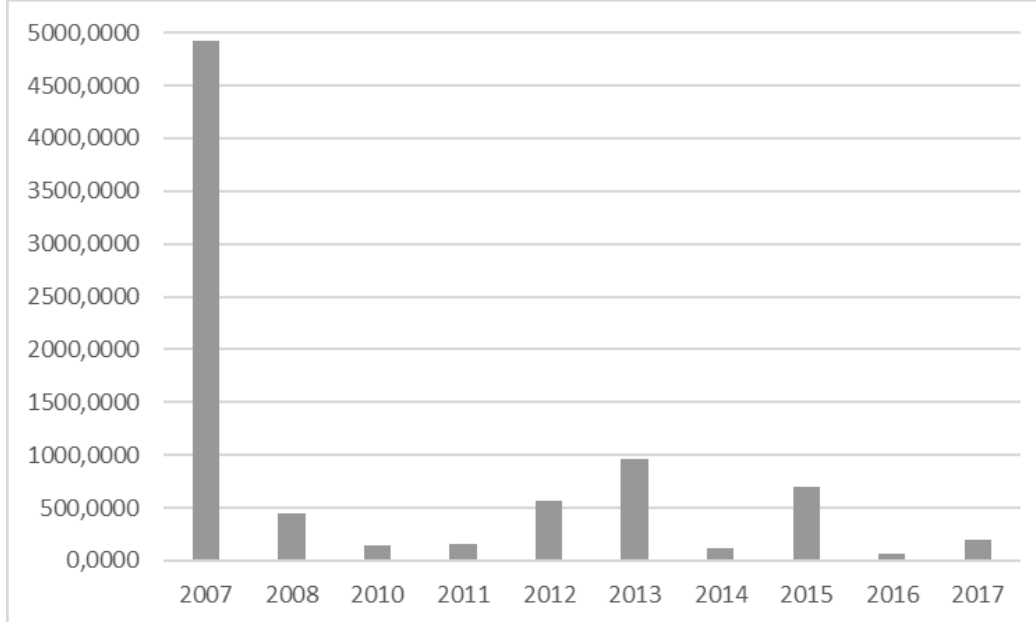

Figure 6. long-term changes in zooplankton biomass in the Danube avandelta. Axis $\mathrm{X}$ - periods, Axis $\mathrm{Y}$ - zooplankton biomass, $\mathrm{mg} / \mathrm{m}^{3}$

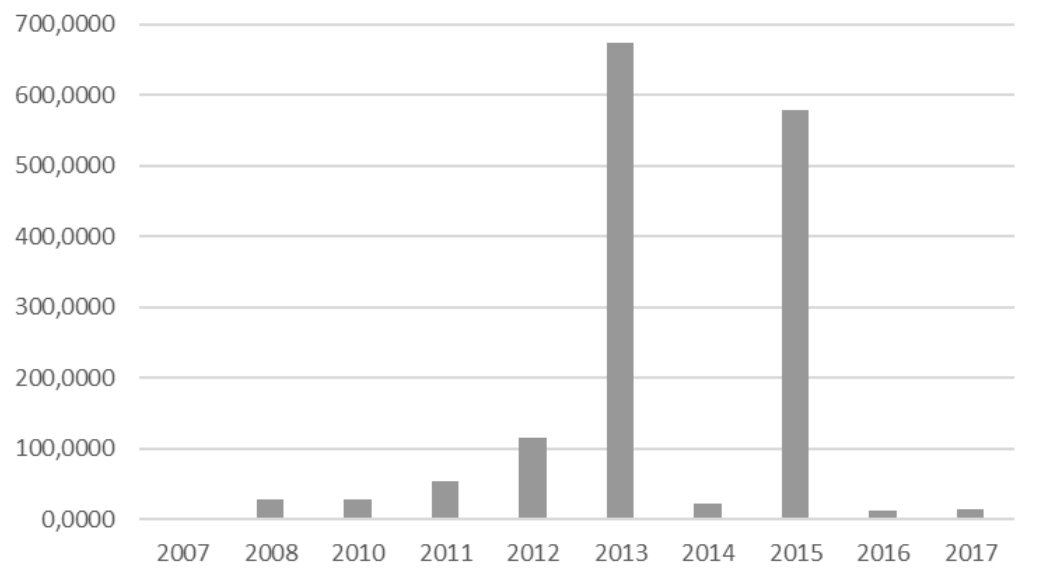

Figure 7. long-term changes of biomass of Copepoda in the Danube avandelta. Axis $\mathrm{X}$ - periods, Axis Y - Copepoda of total zooplankton biomass, \% 
These changes can be regarded as an improvement in the forage base of planktophagous fish.

In Danube avandelta the biomass of Copepoda was increased, reaching maximum indicator in 2013 and 2015, and then decreased again simultaneously with the decrease in the total biomass of zooplankton (Figure 7).

The biomass of Copepoda in recent years had increased in the Danube avandelta, and this indicates an improvement in the quality of the aquatic environment.

\section{Dynamics of the biomass of the $O$. davisae, A. clausi and A. tonsa} in the Odesa and Danube regions of the Black sea in 2016-2019

Based on the results of long-term monitoring was observed a change in the abundance and biomass of the aliens $O$. davisae, A. clausi and $A$. tonsa over the last four years in Danube regions. Indicators of abundance of $O$. davisae are presented in Figure 8.

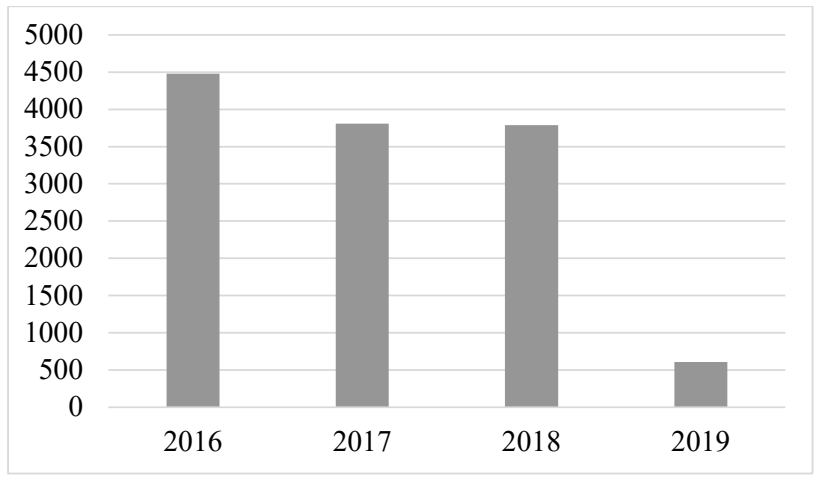

Figure 8. Abundance of $O$. davisae in 2016-2019 in Danube region. Axis $\mathrm{X}$ - periods, Axis $\mathrm{Y}$ - abundance of $O$. davisae, ind. $/ \mathbf{m}^{3}$

In 2016 the average annual indicators of $O$. davisae abundance was 4479.9 ind. $/ \mathrm{m}^{3}$. In 2017 this indicator slightly decreased to 3807.6 and practically did not change in 2018 (3790.5). In 2019 the abundance of this copepod significantly increased up to $607.4 \mathrm{ind} . / \mathrm{m}^{3}$.

It was a similar picture with the biomass of this alien. The highest biomass was in 2016, which had amounted to $26.879 \mathrm{mg} / \mathrm{m}^{3}$, and a tendency 
to decrease was noticeabled in next years. The biomass of $O$. davisae in 2017 and 2018 slightly had decreased, and were the same mostly. In 2019 was a noticeable decrease of this average annual indicator to $3.645 \mathrm{mg} / \mathrm{m}^{3}$ (Figure 9).

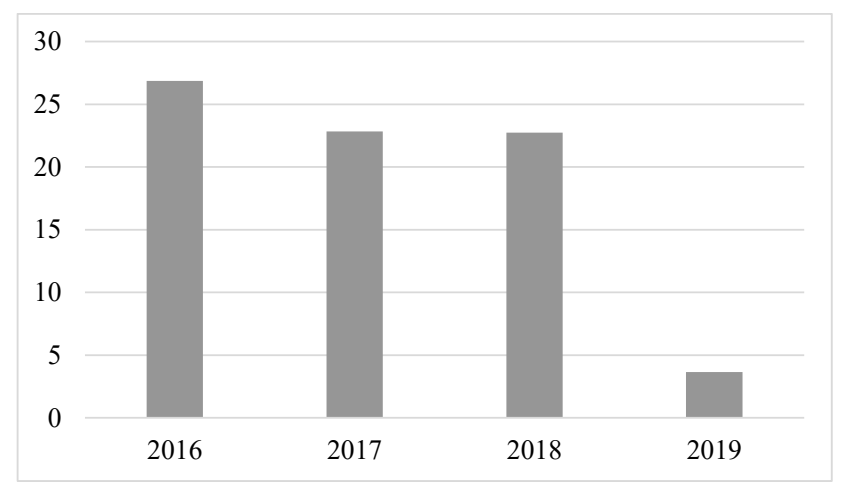

Figure 9. Standard biomass of $O$. davisae, $\mathrm{mg} / \mathrm{m}^{3}$ in 2016-2019 in Danube region.

Axis $\mathrm{X}$ - periods, Axis $\mathrm{Y}$ - biomass of O. davisae, $\mathrm{mg} / \mathrm{m}^{3}$

When had been analyzing changes of $A$. clausi and $A$. tonsa abundance in the Danube region was observed a similar situation with $O$. davisae (Figure 10).

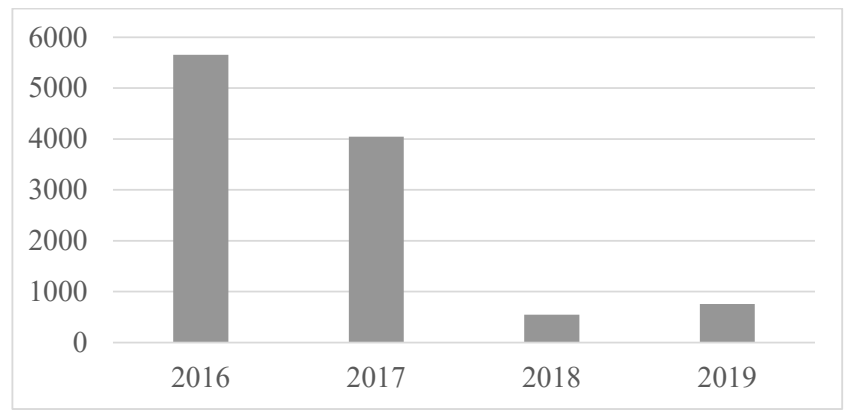

Figure 10. Abundance of $A$. clausi and A. tonsa in 2016-2019 in Danube region. Axis $\mathrm{X}$ - periods, Axis $\mathrm{Y}$ - abundance, ind. $/ \mathrm{m}^{3}$ 
According to the average annual indicators, the largest abundance of A. clausi and A. tonsa in the Danube region were observed in 2016 (5656.22 ind. $/ \mathrm{m}^{3}$ ), which slightly decreased in 2017 to $4044.25 \mathrm{ind} . / \mathrm{m}^{3}$. The next year this metric had decreased significantly to $548.96 \mathrm{ind} . / \mathrm{m}^{3}$. But in 2019 was noticed a slightly increasing of abundance of this species up to 755.16 ind. $/ \mathrm{m}^{3}$.

The biomass of $A$. clausi and $A$. tonsa in the Danube region significantly had changed in recent years (Figure 11).

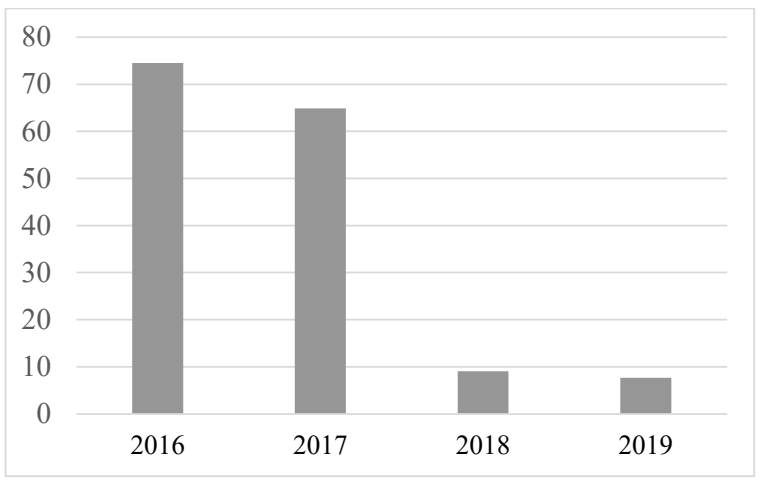

\section{Figure 11. Standard biomass of $A$. clausi and $A$. tonsa, $\mathrm{mg} / \mathrm{m}^{3}$ in 2016-2019 in Danube region. Axis $\mathrm{X}$ - periods, Axis $\mathrm{Y}$ - biomass, $\mathrm{mg} / \mathrm{m}^{3}$}

During this period the highest biomass $A$. clausi and $A$. tonsa were observed in 2016 which was $74.51 \mathrm{mg} / \mathrm{m}^{3}$. In 2017 was a slight decrease to $64.89 \mathrm{mg} / \mathrm{m}^{3}$. The next year this indicator had decreased even more and amounted to $9.03 \mathrm{mg} / \mathrm{m}^{3}$. In 2019 the biomass of this species did not increase $\left(7.67 \mathrm{mg} / \mathrm{m}^{3}\right)$.

As we can see in the last years the abundance and biomass of O. davisae, A. clausi and A. tonsa had decreased. In 2016-2019 these species were the main components of the copepodas crustaceans. Thus, during the investigation had been monitored the dynamics of the biomass of total zooplankton, biomass of Copepoda, biomass of $O$. davisae, $A$. clausi and $A$. tonsa (Figure 12). Also had observed the changing of part of these species from the total biomass of Copepoda in Danube region (Figure 13). 


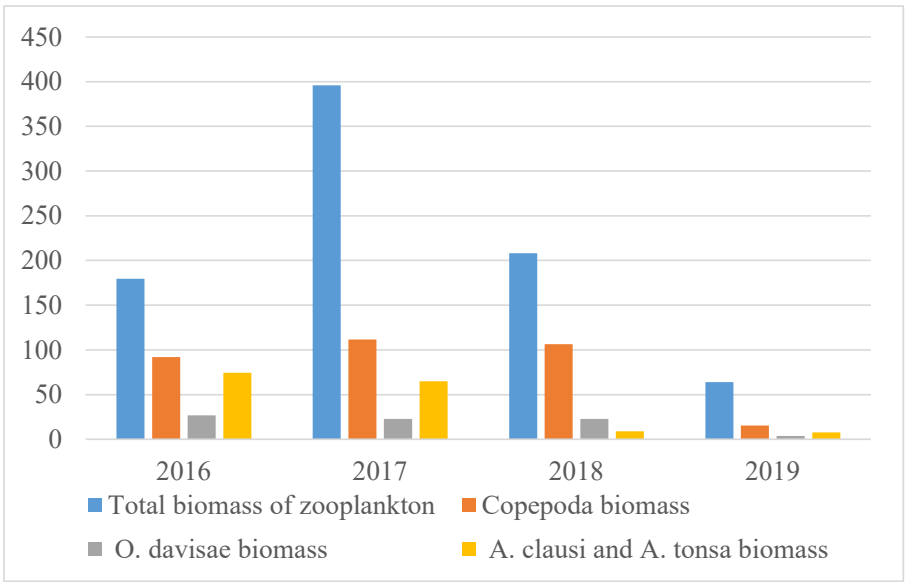

Figure 12. The dynamics of the biomass of total zooplankton, Copepoda, $O$. davisae, $A$. clausi and $A$. tonsa in Danube region in 2016-2019; Axis $X$ - periods, Axis Y - Copepoda of total zooplankton biomass, \%

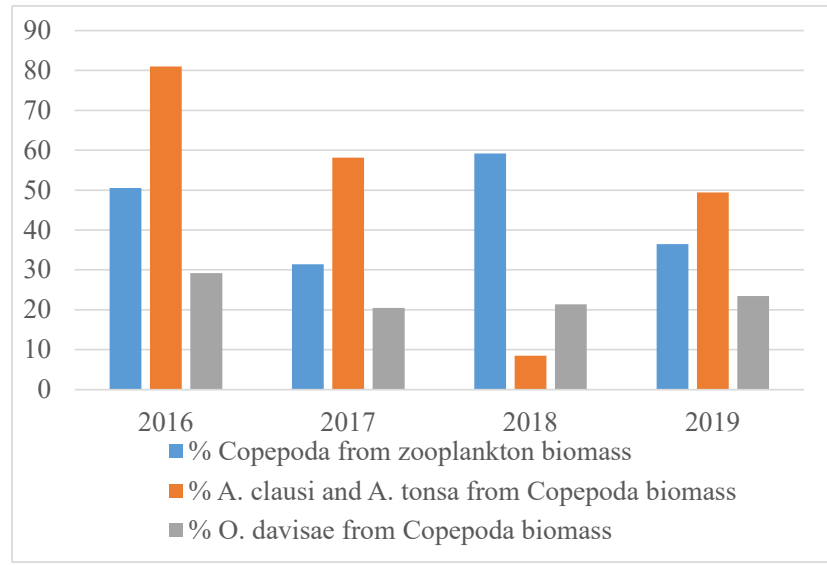

Figure 13. The dynamics of the \% Copepoda of total biomass of, $\% O$. davisae, \% A. clausi and $A$. tonsa of \% Copepoda in Danube region in 2016-2019, Axis $X$ - periods, Axis Y - Copepoda of total zooplankton biomass, \% 
In 2016 the part of $O$. davisae of the \% of Copepoda of the total biomass was more than half $-29.21 \%$. In subsequent years was a slight decreased of $O$. davisae from copepods. In 2017 this metric was $20.5 \%$ but already in $2018 \%$ O. davisae from the Copepoda begins to increase and had amounted to $21.4 \%$, and in $2019-23.46 \%$.

In 2016 the percentage of $A$. clausi and $A$. tonsa from Copepoda biomass were the largest $-80.96 \%$. The next year this metric was $58.16 \%$. In 2018 the part of $A$. clausi and $A$. tonsa from Copepoda were decreased to $8.49 \%$. But in 2019 it had increased to its previous indicators significantly which amounted to $49.4 \%$.

Thus $O$. davisae, A. clausi and $A$. tonsa were the main components of copepods where the part of $A$. clausi and $A$. tonsa from copepods was much higher than part of $O$. davisae. Because these species had acclimatized to the new environment after it was first recorded and gradually both the frequency and its abundance among the Black Sea zooplankton have been increased.

\section{Ecological state of the investigated aquatories by Copepodas indicators}

According to the monitoring data of the North-Western part of the Black Sea (from 2004 to 2019), the water quality class have been determined in such regions: Danube-Dnieper coastal waters, Danube avandelta, northwestern Black Sea bays, shallow and deepwater shelfs. For these regions was calculated the average annual indicators of the biomass of Copepoda (maximum, minimum and average (Table 1).

Table 1

The value of Copepoda biomass from the total biomass of zooplankton (\%) of North-Western part of the Black Sea

\begin{tabular}{|c|c|c|c|c|}
\hline \multirow{2}{*}{ № } & \multirow{2}{*}{ Subregion } & \multicolumn{3}{|c|}{ Biomass of Copepoda, \% } \\
\cline { 3 - 5 } & & Maximum & Minimum & Average \\
\hline 1 & Danube-Dnieper coastal waters (C3) & 169.91 & 4.97 & 48.93 \\
\hline 2 & Danube avandelta (T1) & 98.43 & 0.45 & 45.70 \\
\hline 3 & North-western Black Sea bays (C9) & 88.55 & 8.74 & 36.85 \\
\hline 4 & Shallow shelf (Sh4) & 60.12 & 0 & 14.93 \\
\hline 5 & Deepwater shelf (Sh6) & 56.2 & 0 & 15.48 \\
\hline
\end{tabular}


It is known that the indicator of good quality will if the $\%$ of Copepoda of the total zooplankton biomass, it is more than $45 \%$. According to the results of the long-term monitoring in North-Western part of the Black Sea the ecological state had been different (Figure 14).

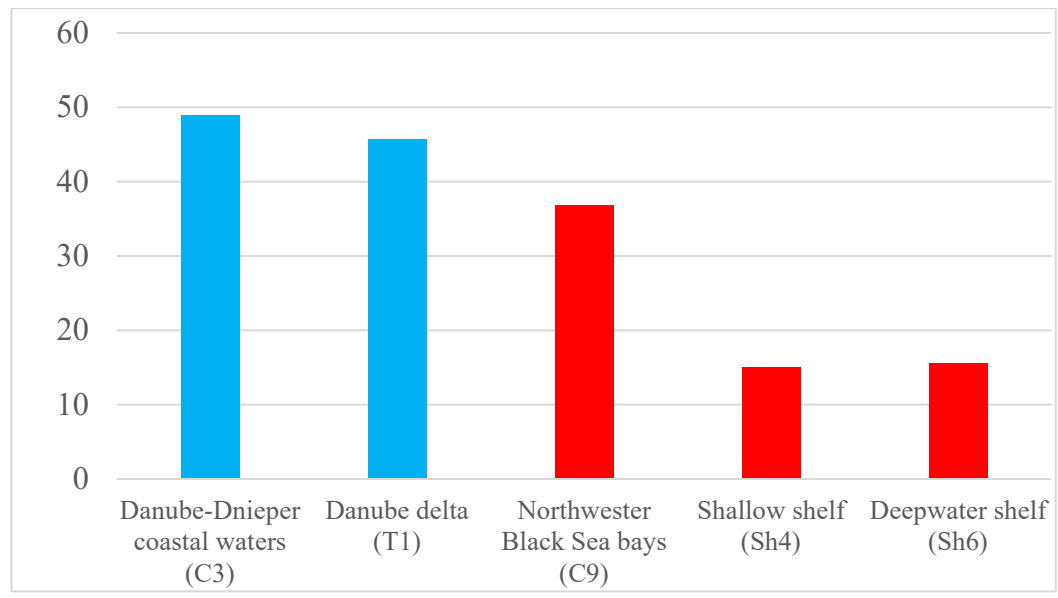

Figure 14. The ecological state of North-Western part of the Black Sea by Copepoda of the total zooplankton biomass (\%) in 2004-2019. Axis X - periods, Axis Y - Copepoda of the total zooplankton biomass (\%), - GES, - not GES

In the period from 2004 to 2017 the ecological state was "good" (GES) only in such equatorials as Danube-Dnieper coastal waters and Danube avandelta where presentence of Copepoda was higher than $45 \%$. In waters of north-western Black Sea bays, shallow and deepwater shelfs was determined the "not good" ecological state (notGES) as the part of Copepoda was lower than $45 \%$.

\section{Conclusions}

When it is impact of anthropogenic eutrophication of any type of aquatic ecosystems the short-cycle organisms and they biomass playing a main role in indicating of water quality. Copepods have short life cycles and they biomass and the part of forage biomass of zooplankton greatly changes due 
to the eutrophic factor. Therefore the Copepoda is considered the indicator of the ecological status of waters bodies.

As a result of the analysis of average annual values the total biomass of zooplankton had decreased considerably in the last years in Odesa and Danube regions. And the largest biomass was observed in the period from 1970 to 1980. In Danube region after 2007 the highest indicator of zooplankton biomass was observed in 2012-2013 and 2015, and in 2016-2019 the biomass had decreased again.

The Copepoda biomass in the Odesa bay was at the same level and practically did not changed from 1970 to 2000 . But in the 2000s was a slight changed to decreasing of this indicator. And from 2011 to the present the biomass of copepods had increased significantly. In the Danube region the dynamics of copepod biomass was different. In Danube avandelta the biomass of Copepoda was increased reaching maximum indicator in 2013 and 2015 and then had decreased again simultaneously with the decreasing in the total biomass of zooplankton.

Biomass of Copepoda in next years was the highest among all the years of the investigation. The total zooplankton biomass and are clearly decreasing in Ukrainian waters and \% of Copepoda from total zooplankton biomass was increasing. These tendencies shown a positive change in the forage base of commercial planktophagous fishes and ecological class status of the investigated aquatories.

From 2016 to 2019 had been tendency to decreasing of the abundance and biomass of species $O$. davisae, A. clause and $A$. tonsa. The higher their indicators were in 2016 and the lowest rates had observed in 2019. This is due to a decreasing in the abundance and biomass of Copepoda.

The parts of the $O$. davisae, A. clausi and A. tonsa of the $\%$ of Copepoda of the total biomass was higher in $2016(29.21 \%$ and $80.96 \%)$ and next years this metrics decreased. In 2019 this indicates had composed $23.46 \%$ and $49.4 \%$ (O. davisae and $A$. clausi and $A$. tonsa respectively). The part of $A$. clausi and A. tonsa from copepods were much higher than part of O. davisae.

In 2004-2017 by the average annual values of biomass of Copepoda (\%) good water quality (GES) had noted in the Danube-Dnieper coastal waters and Danube avandelta. The north-western Black Sea bays, deepwater shelf and shallow shelf subregions had shown a poor ecological status (NotGES). 


\section{References:}

1. Aleksandrov B. G., Kharytonova Yu. V. (2019) Implementatsiia Dyrektyvy ES pro morsku stratehiiu dlia derzhavnoho monitorynhu zooplanktonu morskykh vod Ukrainy [Implementation of the EU Marine Strategy Directive for state monitoring of zooplankton in the sea waters of Ukraine]. Proceedings of the Vseukrainska naukova konferentsiiia «Ievrointehratsiia ekolohichnoi polityky Ukrainy» (Ukraine, Odesa, May 29-31, 2019), Odesa: ODECU, pp. 28-37. (in Ukrainian)

2. Altukhov D. A., Gubanova A. D., Mukhanov V. S. (2014) New invasive copepod Oithona davisae Ferrari and Orsi, 1984: seasonal dynamics in Sevastopol Bay and expansion along the Black Sea coasts. Marine ecology, vol. 35, no. 1, pp. 28-34. DOI: https://doi.org/10.1111/maec.12168

3. Borja A., Galparsoro I., Solaun O., Muxika I., Tello E. M., Uriarte A., et al. (2006) The European Water Framework Directive and the DPSIR, a methodological approach to assess the risk failing to achieve good ecological status. Estuarine, coastal and shelf science, vol. 66, pp. 84-96. DOI: http://dx.doi.org/10.1016/ j.ecss.2005.07.021

4. Funda Ü., Tuba T. K. (2016) First report of the occurrence of Oithona davisae Ferrari F.D.\&Orsi, 1984 (Copepoda: Oithonidae) in the Southern Black Sea, Turkey. Turkish journal of fisheries and aquatic sciences, vol. 16, pp. 413-420. DOI: https://doi.org/10.4194/1303-2712-v16_2_21

5. Gubanova A. (2000) Occurrence of Acartia tonsa Dana in the Black Sea. Was it introduced from the Mediterranean? Mediterranean Marine Science, vol. 1, no. 1, pp. 105-109. DOI: https://doi.org/10.12681/mms.281

6. Gubanova A. D., Garbazey O. A., Popova E. V., Altukhov D. A., Mukhanov V. S. (2019) Oithona davisae: naturalizatsiya v Chernom more, mezhgodovyie i sezonnyie mzmeneniya, vlshiyanie na strukturu soobschestva planktonnyih kopepod [Oithona davisae: naturalization in the Black Sea, interannual and seasonal dynamics, and effect on the structure of the planktonic Copepod's Community]. Oceanology, vol. 59, pp. 912-919. DOI: https://doi.org/10.1134/ S0001437019060079 (in Russian)

7. Gubareva E. S., Svetlichnyiy L. S. (2016) Kopepodyi Oithona similis i Oithona davisae - dve strategii ekologo-fiziologicheskoy adaptatsii v Chernom more [Copepods Oithona similis and Oithona davisae - two strategies of ecological and physiological adaptation in the Black Sea]. Oceanology, vol. 56, no. 2, pp. 258-265. DOI: https://doi.org/10.7868/S0030157416020088 (in Russian)

8. Kharytonova Yu. V., Diadychko V. H. (2020) Analiz ekolohichnoho stanu pivnichno-zakhidnoi chastyny Chornoho moria za pokaznykamy zooplanktonu zghidno zi standartamy Dyrektyvy YeS pro morsku stratehiiu [Analysis of the ecological status of the north-western part of the Black Sea according to zooplankton indicators in accordance with the standards of the EU Marine Strategy Directive]. Proceedings of the «Monitorynh ta okhorona bioriznomanittia $v$ Ukraini: tvarynnyi svit. Seriia: Conservation biology in Ukraine» (Ukraine, Kiev, March 27, 2020), Kyiv-Chernivtsi: Druk-Art, vol. 16, no. 2, pp. 221-229. (in Ukrainian)

9. Kharytonova Y. V., Nabokin M. V. (2020) Zooplankton of the Northwestern part of the Black Sea in 2016-2019 and assessment of the quality 
of the environment by its indicators. Scientific developments of Ukraine and $E U$ in the area of natural sciences, vol. 2, pp. 685-700. DOI: https://doi.org/ 10.30525/978-9934-588-73-0/2.16

10. Mihneva V., Stefanova K. (2013) The non-native copepod Oithona davisae (Ferrari F.D. and Orsi, 1984) in the Western Black Sea: seasonal and annual abundance variability. BioInvasions Records, vol. 2, no. 2, pp. 119-124. DOI: 10.3391/ bir.2013.2.2.04

11. Vorobova L. V., Kulakova I. I., Synohub I. O., Polishchuk L. M., Nesterova D. A., Bondarenko O. S., et al. (2017) Odeskyi rehion Chornoho moria: hidrobiolohiia pelahiali $i$ bentali [Odessa region of the Black Sea: hydrobiology of pelagic and bental]. Alexandrov B. G. (ed.). Odesa: Astroprint. (in Russian)

12. Polishchuk L. N., Nastenko E. V. (2006) Mezo- i makrozooplankton [Mesoand macrozooplankton]. Zaitsev Yu. P., Alexandrov B. G., Minicheva G. G. (eds.). Severo-zapadnaya chast Chernogo morya: biologiya i ekologiya [Northwest Black Sea: Biology and ecology]. Kyiv: Naukova Dumka, pp. 229-237. (in Russian)

13. Salazkin A. A., Ivanova M. B., Ogorodnikova V. A. (1984) Metodicheskie rekomendatcii po sboru i obrabotke materialov pri gidrobiologicheskikh issledovaniiakh. Zooplankton i ego produktciia [Methodical recommendations for the collection and processing of materials in hydrobiological research. Zooplankton and its products]. Leningrad: ZIN. (in Russian)

14. Zaitsev Y. P. (1992) Recent changes in the trophic structure of the Black Sea. Fisheries oceanography, vol. 11, pp. 80-189. DOI: https://doi.org/ 10.1111/j.1365-2419.1992.tb00036.x

15. Zaitsev Y. P., Alexandrov B. G., Minicheva G. G. (2006) Severo-zapadnaya chast Chernogo morya: biologiya i ekologiya [Northwestern part of the Black Sea: biology and ecology]. Kyiv: Naukova Dumka. (in Russian) 